\title{
PENGGUNAAN TINDAKAN TEMBAK DI TEMPAT TERHADAP PELAKU TERORISME OLEH DENSUS 88 DIKAITKAN DENGAN ASAS PRADUGA TIDAK BERSALAH
}

\author{
Agus Salem \\ Program Magister Ilmu Hukum, Universitas Ekasakti \\ Email: agussalem@gmail.com
}

\begin{abstract}
In recent years terrorism has become increasingly prevalent and shootings have often been carried out against terrorists against the police. In action against the perpetrators of theorism, Densus 88 often took action to place a shot. Such actions cause opposition to the principle of presumption of innocence. The specifications in this study are descriptive analytical. The results of the study are the rule of law which is the basis of the shooting in place against terrorists is Article 50 and 51 of the Criminal Code. The Chief of Police Regulation No. 1 of 2009 concerning the use of force in the Police Action is a number of basic principles on which firearms are used. Detachment 88 as the perpetrator of terrorism crackdown operations must pay attention to the principle of presumption of innocence by avoiding arbitrary actions and being outside the established procedures, both in law and other regulations.
\end{abstract}

Keywords: Terrorism, Shoot on the spot, Detachment 88, the principle of presumption of innocence

\section{PENDAHULUAN}

Terorisme termasuk kategori extra ordinary crimes, tentu membutuhkan extra ordinary measures. Sehingga kelahiran undang-undang terorisme ini tidak lepas dari munculnya pro dan kontra.(Indriyanto Seno Adji, 2001;34) Tindak pidana terorisme sendiri di atur didalam Undang-Undang Nomor 15 Tahun Tahun 2003 tentang Pemberantasan Tindak Pidana Terorisme. Pasal 1 angka 2 Undang-Undang Nomor 15 Tahun 2013 menyatakan Tindak Pidana Terorisme adalah segala perbuatan yang memenuhi unsur tindak pidana sesuai dengan ketentuan yang terdapat dalam UndangUndang yang mengatur tindak pidana terorisme. Dalam operasi, banyak dilakukan kekerasan bahkan penembakan mati kepada orang yang disangka atau bahkan baru diduga melakukan tindak pidana terorisme. Seperti yang baru saja terjadi pada terduga pelaku tindak pidana terorisme yang membakar Polres Dharmasraya, pihak kepolisian mengambil sikap represif dengan menembak mati kedua terduga pelaku karena dinilai mengancam keselamatan pihak kepolisian dan warga sekitar dengan melakukan perlawanan dengan menembakan panah kearah petugas.

Di satu sisi tindakan ini tidak berlandaskan hukum karena belum ada keputusan yang memiliki hukum tetap untuk 
mengeksekusi mati dari kedua terduga pelaku tindak pidana terorisme ini, namun disisi lain pihak kepolisian juga harus mengambil keputusan yang cepat dan tepat dalam menangani kedua terduga tersebut karena telah membahayakan dengan menembakan panah kearah petugas. cara-cara yang umum digunakan dalam tindakan terorisme, diantaranya adalah pengeboman /teror bom, pembajakan, serangan militer dan pembunuhan, perampokan, penculikan dan penyanderaan, dan dengan cara serangan bersenjata. Motif dari tindak pidana terorisme tersebut bersifat kompleks, karena tidak hanya dari faktor psikologis, namun juga faktor politik, agama, sosiologis, sosial budaya dan faktor lain yang bersumber daripada tujuan yang ingin dicapai.

Indonesia sendiri menganut azas presumption of innoncent atau azas praduga tidak bersalah. Asas umum yang harus ada terkait hak tersangka di mata hukum adalah presumption of inocence (Praduga Tak Bersalah), yakni sebelum ada putusan pengadilan seseorang masih dinyatakan tidak bersalah termasuk masih dijunjung Hak Asasi Manusia. (M.Fall, 1991;32) Azas praduga tidak bersalah memiliki pemahaman bahwa sebuah perkara yang belum memiliki kekuatan hukum tetap maka terduga/ tersangka/ terdakwa wajib dianggap tidak bersalah.

Berdasarkan latar belakang yang dipaparkan di atas, maka permasalahan yang akan dibahas adalah aturan hukum tentang pengunaan tindakan tembak di tempat terhadap terduga pelaku tindak pidana terorisme di Indonesia dan Tindakan tembak di tempat terhadap pelaku tindak pidana terorisme bila dikaji dari asas praduga tak bersalah.

\section{METODE PENELITIAN}

Spesifikasi penelitian adalah deskriptif analisis, dengan metode pendekatan yuridis normatif. Jenis data yang digunakan adalah data sekunder. Data sekunder diperoleh dari studi dokumen dan studi kepustakaan Teknik pengumpulan data dengan penelusuran bahan bahan hukum sebagai data sekunder. Data yang diperoleh kemudian dianalisa secara kualitatif .

\section{HASIL PENELITIAN DAN ANALISIS}

\section{Aturan Hukum Tentang Tembak Mati} Terhadap Pelaku Terorisme

Pelaksanaan kewenangan tembak di tempat yang dimiliki oleh anggota Polri dalam melaksanakan tugasnya harus sesuai dengan dasar hukum pelaksanaan kewenangan tembak di tempat serta sesuai dengan situasi dan kondisi kapan perintah tembak di tempat itu dapat diberlakukan, dan juga dalam pelaksanaan perintah tembak di tempat harus sesuai dengan asas tujuan, keseimbangan, asas keperluan, dan asas kepentingan. 
Pada dasarnya tindakan tembak di tempat menjadi prioritas apabila posisi petugas terdesak dan pelaku mengancam keselamatan anggota Kepolisian Republik Indonesia. Dalam pelaksanaan kewenangan tembak di tempat harus mnenghormati hak hidup dan hak bebas dari penyiksaaan karena kedua hak itu dijamin dengan undang undang. Perlunya pemahaman mengenai kode etik dan prinsip dasar penggunaan senjata api oleh anggota Polri dalam pelaksanaan kewenangan tembak di tempat agar nantinya dalam pelaksanaan kewenangan tembak di tempat itu tidak melanggar hukum.

Hal yang terpenting dalam pelaksanaan perintah tembak di tempat harus sesuai dengan mekanisme pelaksanaan tembak di tempat dan prosedur tetap penggunaan senjata api oleh Polri. Dalam setiap melakukan tindakan tembak di tempat Polisi selalu berpedoman pada suatu kewenangan yaitu kewenangan bertindak menurut penilaiannya sendiri, hal ini yang sering disalahgunakan oleh oknum anggota kepolisian.

Beberapa aturan hukum yang menjadi dasar dari dilakukannya tembak di tempat terhadap teroris adalah Pasal 48 KUHP yang berbunyi barang siapa melakukan perbuatan karena adanya daya paksa (Overmacht) tidak dipidana. Dalam hal melakukan tembak mati di tempat pada proses penangkapan oleh Kepolisian Republik Indonesia terdapat daya paksa yang bersifat darurat karena polisi melakukan tembak mati di tempat untuk menghindarkan jatuhnya korban baik dari pihak polisi maupun masyarakat.

Dalam Pasal 49 ayat (1) KUHP mengatur tentang Pembelaan Terpaksa (Noodweer). Penembakan mati dalam proses penangkapan terorisme oleh Kepolisian Republik Indonesia ialah keadaan yang terpaksa karena tidak ada jalan lain dan dalam hal mempertahankan hak yang didahului dengan serangan.

Dalam penjelasannya disebutkan, pembelaan terpaksa itu hanya bisa dilakukan berdasarkan prinsip keseimbangan, kalau yang diserang atau diancam masih bisa menghindar atau melarikan diri, janganlah polisi memaksakan diri untuk melakukan penembakan dengan dalih pembelaan terpaksa.

Dalam pasal 50 KUHP yang menyatakan barang siapa melakukan perbuatan untuk menjalankan peraturan undang-undang. Pada Pasal 51 KUHP ayat (1) yang menyatakan barang siapa melakukan perbuatan untuk menjalankan perintah jabatan yang diberikan oleh kuasa yang berhak akan itu, tidak boleh dihukum. Tindakan lain yang dimaksud dalam angka 10 Pasal 7 Kitab Undang undang Hukum Acara Pidana (KUHAP) adalah termasuk melakukan tembak mati di tempat pada orang yang di duga atau tersangka yang terkait 
dalam suatu tindak pidana termasuk kejahatan terorisme.

Kewenangan diskresi tersebut harus tetap dalam koridor hukum sehingga diskresi tersebut mempunyai manfaat bagi penegakan hukum dan tentunya dengan tidak melanggar hukum. Kewenangan diskresi harus selalu mempunyai rambu-rambu pembatas karena penggunaan diskresi yang tidak salah gunakan harus dapat dikendalikan secara internal melalui kode etik profesi.

Dasar hukum diskresi bagi petugas kepolisian negara Republik Indonesia (Polri) dalam melaksanakan tugasnya dapat dilihat pada Undang-undang Nomor 2 tahun 2002 tentang Kepolisian Negara Republik Indonesia Pasal 15 ayat (2) huruf k, Pasal 16 ayat (1) huruf 1 : dan Pasal 18 ayat (1) Untuk kepentingan umum, pejabat Kepolisian Negara Republik Indonesia dalam melaksanakan tugas dan wewenangnya dapat bertindak.

Pasal 15 Peraturan Kapolri Nomor 1 Tahun 2009 tentang penggunaan kekuatan dalam Tindakan Kepolisan ada beberapa prinsip dasar yang menjadi dasar pengunaan senjata api.

Dalam Peraturan Kepala Kepolisian Negara Republik Indonesia Nomor 1 Tahun 2009 Tentang Penggunaan Kekuatan Dalam Tindakan Kepolisian pada Pasal 8 ayat (1) yang menyatakan penggunaan kekuatan dengan kendali senjata api dilakukan ketika:
1. Tindakan pelaku kejahatan atau tersangka dapat secara segera menimbulkan luka parah atau kematian bagi anggota Polri atau masyarakat;

2. Anggota Polri tidak memiliki alternatif lain yang beralasan dan masuk akal untuk menghentikan tindakan atau perbuatan pelaku kejahatan atau tersangka tersebut;

3. Anggota Polri sedang mencegah larinya pelaku kejahatan atau tersangka yang merupakan ancaman segera terhadap jiwa anggota Polri atau masyarakat.

Mengenai aturan tembak mati juga dapat dilihat dalam tentang Peraturan Kapolri Nomor 8 tahun 2009 tentang Implementasi Prinsip dan Standar Hak Asasi Manusia dalam Penyelenggaraan Tugas Kepolisian Republik Indonesia. Penggunaan senjata api dalam Pasal 47 Peraturan Kapolri Nomor 8 tahun 2009 tentang Implementasi Prinsip dan Standar Hak Asasi Manusia dalam Penyelenggaraan Tugas Kepolisian Republik Indonesia.

\section{Tindakan Tembak Di Tempat Terhadap} Pelaku Tindak Pidana Terorisme Dikaitkan Dengan Asas Praduga Tak Bersalah

Unsur utama yang bisa melakukan pencegahan aksi teror adalah intelijen. Penguatan intelijen diperlukan untuk melakukan pencegahan lebih baik. Sistem deteksi dini dan peringatan dini atas aksi teror perlu dilakukan sehingga pencegahan 
lebih optimal dilakukan. Unsur pembentuk teror ada sembilan.

Intelijen bisa melakukan pencegahan aksi teror dengan memutus salah satu dari sembilan unsur pembentuk teror, walaupun kelompok dan individu pelaku teror terus melakukan inovasi dalam menjalankan aksinya. Penguasaan teknologi untuk memantau transaksi keuangan dan data percakapan orang yang diduga mempunyai ideologi radikal perlu dilakukan untuk membaca dan mengetahui aksi-aksi yang akan dilakukan sebagai bahan pencegahan.

Penguatan intelijen tentu tidak hanya dari sisi teknis tetapi dari sisi politis. UU tentang Intelijen dan UU tentang Tindak Pidana Terorisme perlu disesuaikan supaya terorisme ditangani dengan porsi terbesar pada pencegahan bukan pada penindakan. Selain itu penguatan BNPT perlu dilakukan agar mempunyai kewenangan dan energi untuk melakukan pemberantasan terorisme seperti BNN yang memberantas narkoba dan KPK yang memberantas korupsi.

Terkait dengan penindakan aksi teror, kemampuan Polri terutama Densus 88/AT tidak perlu diragukan lagi. Kasus-kasus terorisme di Indonesia berhasil diungkap dan ditangkap pelakunya. Pencegahanpencegahan berhasil dilakukan dengan barang bukti yang signifikan. Penindakan yang dilakukan oleh Densus 88 walaupun menjadi kontroversi bagi pihak-pihak tertentu perlu didukung. Upaya-upaya yang dilakukan oleh pihak yang ingin melemahkan Densus 88 harus dicegah, karena akan menjadi celah bagi terjadinya aksi teror.

Tahap pemulihan perlu mendapatkan perhatian yang serius. BNPT sebagai lembaga negara yang bertanggung jawab atas pemberantasan terorisme perlu mengkaji kembali program deradikalisasi yang dilakukan. Narapidana tindak pidana terorisme perlu diperlakukan secara khusus sehingga selama menjalani hukuman sekaligus menjalani program deradikalisasi, bukan malah menerima program penguatan radikalisasi dari narapidana lainnya, atau menggalang napi lain untuk bergabung

Prosedur-prosedur yang dilakukan dengan benar dan memperhatikan semua hal dalam proses penangkapan yang menyebabkan penembakan pada terduga atau tersangka teroris oleh anggota Kepolisian Republik Indonesia tidak dapat diminta pertanggungjawabannya karena dilindungi oleh alasan Pembenar yang menyatakan adanya daya paksa atau "overmacht" (Pasal 48 KUHP), pembelaan terpaksa atau “noodweer" (Pasal 49 ayat (1) KUHP), karena sebab menjalankan perintah undangundang (Pasal $50 \quad$ KUHP), karena melaksanakan perintah jabatan yang sah (Pasal 51 ayat (1) KUHP).

Tanpa adanya ancaman atau perlawan dari pihak penyerang Polisi maka penggunaan senjata api harus dihindarkan karena dapat terjadi kesengajaan untuk 
melindungi dan mempertahankan kepentingan hukumnya agar tetap hidup tanpa memandang kepentingan hidup pelaku kejahatan terorisme.

Kesengajaan menghilangkan nyawa orang lain oleh anggota Kepolisian Republik Indonesia dalam melaksanakan kewajibannya di luar kebutuhan untuk melakukan pembelaan terpaksa dapat diminta pertanggungjawabannya sesuai dengan Pasal 13 ayat (1) Peraturan Kepala Kepolisian Negara Republik Indonesia Nomor 1 Tahun 2009 Tentang Penggunaan Kekuatan Dalam Tindakan Kepolisian yang menyatakan Setiap individu anggota Polri wajib bertanggung jawab atas pelaksanaan penggunaan kekuatan dalam tindakan kepolisian yang dilakukannya dan Pasal 49 ayat (1) huruf a yang menyatakan setiap petugas wajib mempertanggung jawabkan tindakan penggunaan senjata api. Dimana, alasan pembenar tidak dapat digunakan karena melakukan penggunaan senjata api tidak sesuai peraturan perundang-undangan yang menghapuskan sifat melawan hukumya karena menjalankan undang-undang.

Menurut penjelasan Memorie van Toelichting (MVT) dapat diketahui anggota Kepolisian mendapat jaminan tidak dipidana karena telah melakukan sesuatu perbuatan untuk melaksanakan peraturan perundangundangan telah diwajibkan untuk melakukan perbuatan tertentu, dan bukan orang yang diberikan hak untuk melakukan perbuatan tertentu. Ini sesuai dengan pendapat Noyon dan Langemeijer yang mengatakan untuk melaksanakan peraturan perundang undangan, orang hanya dapat melakukan suatu perbuatan itu sebagai kewajiban dan bukan seseorang mempunyai hak untuk berbuat demikian.

Dengan tidak sesuai prosedurnya pihak Kepolisian Republik Indonesia melakukan penangkapan yang menyebabkan kematian pada terduga atau tersangka terorisme dimana dalam penangkapan dan penembakan mati dilakukan dengan sewanang-weanang maka pihak kepolisian dapat diminta pertanggungjawabannya karena terdapat kesalahan dalam melaksanakan tugasnya dan melanggar asas praduga tidak bersalah, karena tidak sesuai dengan amanat Pasal 48 Kitab Undang-undang Hukum Pidana (KUHP) tentang daya paksa yang disebabkan adanya perlawanan atau ancaman dari pihak pelaku terorisme. Dimana tidak terdapat daya paksa batin dan psikis yang mengharuskan anggota Kepolisian melepaskan tembakan yang berujung pada kematian.

Penggunaan senjata api tetap dilakukan maka anggota kepolisian berbuat kesalahan. Tidak terpenuhiya alasan-alasan pembenar ini menyebabkan anggota kepolisian dalam melakukan proses penangkapan yang menyebabkan hilangnya nyawa orang lain baik terduga maupun tersangka pelaku kejahatan terorisme dapat diminta pertanggungjawaban pidananya karena 
adanya unsur kesalahan baik kesengajaan maupun kelalaian dan mampunya anggota Kepolisian Republik Indonesia untuk bertanggungjawab.

Adanya kebijakan operasi penumpasan teroris yang dilakukan oleh Densus 88 sebagai bagian dari Kepolisian Republik Indonesia memberikan kesan bahwa pemerintah mengedepankan pendekatan legal, formal, dan represif dalam menumpas terorisme di Indonesia. Pendekatan yang legal dan formal memang wajib untuk dilakukan, lalu bagaimana dengan pendekatan represif?

Dalam melakukan kebijakan operasi penumpasan teroris, harus benar-benar diperhatikan asas praduga tak bersalah (presumption of innocence) terhadap para tersangka tindak pidana terorisme. Oleh karena itu, Densus 88 sebagai pelaku operasi penumpasan terorisme harus memperhatikan asas praduga tak bersalah dengan cara menghindari tindakan yang sewenangwenang dan berada di luar prosedur yang telah ditetapkan, baik dalam undang-undang maupun peraturan lainnya. Tindak pidana terorisme memang bisa dikategorikan sebagai kejahatan luar biasa, namun dalam penumpasannya harus tetap memperhatikan asas praduga tak bersalah itu. Adanya keharusan untuk memperhatikan asas praduga tak bersalah ini erat kaitannya dengan pemenuhan hak asasi manusia yang dimiliki oleh para tersangka terorisme, terutama hak hidup. Pada kasus- kasus di atas, sebagian besar tersangka terorisme yang ditembak adalah Warga Negara Indonesia yang dijamin hak hidupnya oleh UndangUndang Dasar 1945: "Setiap orang berhak mempertahankan hidup dan kehidupannya."

Oleh karena itu, prosedur tembak di tempat yang diberlakukan kepada tersangka terorisme yang terdapat pada kasus di atas, tidak mengedepankan asas praduga tak bersalah sehingga kemudian berdampak pada hak hidup para tersangka terorisme. Terlepas dari 'perlawanan' yang dilakukan oleh para tersangka ketika hendak ditangkap, Densus 88 seharusnya sedapat mungkin menangkap hidup tersangka terorisme. Densus 88 tidak perlu terus-menerus berdalih bahwa tersangka menyerang atau melawan sehingga harus ditembak mati. Sebagai polisi yang terlatih, Densus 88 seharusnya bisa 'melumpuhkan' bukan menembak mati tersangka terorisme sehingga tersangka terorisme bisa diproses untuk kemudian dapat memberikan keterangan di hadapan pengadilan.

Pada Peraturan Presiden Republik Indonesia Nomor 52 Tahun 2010 tentang Susunan Organisasi dan Tata Kerja Kepolisian Negara Republik Indonesia, Densus 88 bertugas menyelenggarakan fungsi intelijen, pencegahan, investigasi, penindakan, dan bantuan operasional dalam rangka penyelidikan dan penyidikan tindak pidana terorisme. 
Dalam tugas yang ditetapkan peraturan presiden tersebut, jelas bahwa tugas Densus 88 adalah untuk membantu penyelidikan dan penyidikan tindak pidana terorisme sehingga konsekuensinya Densus 88 harus sekuat tenaga untuk 'menyelamatkan' tersangka terorisme agar dapat diselidik dan disidik lebih lanjut. Oleh karena itu, dalam menjalankan tugasnya, Densus 88 juga harus memperhatikan hak asasi tersangka, terutama hak hidup. Selain itu, dalam melaksanakan tugasnya, Densus 88 perlu memperhatikan asas- asas dalam Konvensi Menentang Penyiksaan dan Perlakuan atau Penghukuman Lain yang Kejam, Tidak Manusiawi, dan Merendahkan Martabat Manusia. Adapun konvensi tersebut telah diratifikasi oleh Indonesia dengan UndangUndang Nomor 5 Tahun 1998.

Dalam konvensi tersebut, yang dimaksud dengan penyiksaan adalah: setiap perbuatan yang dilakukan dengan sengaja, sehingga menimbulkan rasa sakit atau penderitaan yang hebat, baik jasmani maupun rohani, pada seseorang untuk memperolah pengakuan atau keterangan dari orang itu atau dari orang ketiga, dengan menghukumnya atas suatu perbuatan yang telah dilakukan atau diduga telah dilakukan oleh orang itu atau orang ketiga, atau mengancam atau memaksa orang itu atau orang ketiga, atau untuk suatu alasan yang didasarkan pada setiap bentuk diskriminasi, apabila rasa sakit atau penderitaan tersebut ditimbulkan oleh, atas hasutan dari, dengan persetujuan, atau sepengetahuan pejabat publik.

Tindakan yang dilakukan oleh Densus 88 dapat dikategorikan sebagai penyiksaan karena dilakukan dengan sengaja sehingga menimbulkan rasa sakit atau penderitaan yang hebat. Dalam definisi penyiksaan di atas, juga disebutkan bahwa penyiksaan dilakukan dengan menghukum atas suatu perbuatan yang telah dilakukan atau diduga telah dilakukan. Tindakan Densus 88 yang menembak mati para tersangka terorisme, dapat dikategorikan sebagai 'hukuman' atas perbuatan yang diduga telah dilakukan, yaitu tindak pidana terorisme.

Selain itu, dalam konvensi ini disebutkan bahwa negara yang meratifikasi konvensi ini harus menjamin bahwa pendidikan dan informasi mengenai larangan terhadap penyiksaan seluruhnya dimasukan dalam pelatihan bagi para aparat penegak hukum yang ada kaitannya dengan penahanan, dan interogasi, atau perlakuan terhadap setiap orang yang ditangkap, ditahan, atau dipenjara. Selain itu, negara juga harus senantiasa mengawasi secara sistematik peraturan-peraturan tentang interogasi, instruksi, metode, kebiasaankebiasaan dan peraturan untuk melakukan penahanan serta perlakuan terhadap orangorang yang ditangkap, ditahan atau dipenjara dalam setiap wilayah kewenangan 
hukumnya, dengan maksud untuk mencegah terjadinya kasus penyiksaan.

Oleh karena itu, untuk melaksanakan ketentuan dalam konvensi ini, negara harus menjamin dan mengawasi agar Densus 88 sebagai salah satu penegak hukum, tidak melakukan penyiksaan terhadap tersangka tindak pidana terorisme. Densus 88 merupakan bagian dari Kepolisian Negara Republik Indonesia, dan Kepolisian Negara Republik Indonesia berada di bawah presiden. Oleh karena itu, presiden berkewajiban juga untuk memastikan bahwa Kepolisian Negara Republik Indonesia dapat melaksanakan konvensi ini sehingga Densus 88 sebagai bagian dari Kepolisian Negara Republik Indonesia bisa lebih manusiawi dalam memperlakukan tersangka tindak pidana terorisme.

Densus 88 sebagai unit dalam Kepolisian Negara Republik Indonesia yang sangat terlatih, seharusnya bisa meniru sepak terjang pasukan Amerika Serikat dan Indonesia yang dapat menangkap dua buronan besar seperti Hambali (tertangkap di Ayutthaya Thailand tahun 2003) dan Umar Al Faruq (tertangkap di Bogor tahun 2002) tanpa harus membunuh mereka. Sebagai bagian dari Kepolisian Negara Republik Indonesia, seharusnya Densus 88 hanya berupaya melumpuhkan sasaran dengan berbagai cara yang patut dan tepat, namun tetap bermoral dan humanis, sesuai dengan doktrin kamtibmas. Oleh karena itu, operasi penumpasan teroris yang dilakukan Densus 88 terhadap kelompok orang yang diduga pelaku teroris di beberapa tempat belakangan ini yang kebanyakan sasarannya langsung dieksekusi mati, sebenarnya tidak perlu dilakukan.

Densus 88 hendaknya menyadari bahwa tuduhan sebagai anggota jaringan teroris kepada mereka sesungguhnya baru merupakan dugaan sehingga operasi yang dilakukan dan akhirnya menyebabkan kematian para tersangka teroris merupakan pelanggaran asas praduga tak bersalah (presumption of innocence). Oleh karena itu, kebijakan operasi penumpasan teroris yang dilakukan oleh Densus 88 harus menjunjung tinggi penghormatan terhadap hak asasi tersangka sebagai orang yang tidak bersalah sebelum diputuskan oleh pengadilan (Pasal 18 ayat 1 Undang-Undang Nomor 39 Tahun 1999 tentang HAM). Terlepas dari tujuan lain yang menyebabkan Densus 88 harus menembak mati para tersangka terorisme pada kasus di atas, Densus 88 seharusnya menyadari bahwa mereka memiliki peran sebagai penegak hukum dan pemelihara keamanan dan ketertiban masyarakat sehingga dalam menjalankan tugasnya untuk melakukan operasi penumpasan teroris, tetap menghargai hukum dengan menjunjung asas praduga tak bersalah serta menghormati hak asasi manusia, terutama hak hidup. Densus 88 akan lebih dihargai apabila sangat 
menjunjung tinggi hukum dan hak asasi manusia ketika menjalankan tugasnya.

\section{PENUTUP}

Aturan hukum yang menjadi dasar dari dilakukannya tembak di tempat terhadap teroris adalah Pasal 48 KUHP tentang adanya daya paksa (Overmacht). Pasal 49 ayat (1) KUHP mengatur tentang Pembelaan Terpaksa (Noodweer), Pasal 50 KUHP yang menyatakan barang siapa melakukan perbuatan untuk menjalankan peraturan undang-undang, tidak boleh di hukum. Polisi yang menembak mati dalam proses penangkapan harus dilihat apakah seimbang apa tidak dalam hal penggunaan senjata api . Pada Pasal 51 KUHP ayat (1) yang menyatakan barang siapa melakukan perbuatan untuk menjalankan perintah jabatan yang diberikan oleh kuasa yang berhak akan itu, tidak boleh dihukum.

Tindakan lain yang dimaksud dalam angka 10 Pasal 7 Kitab Undang undang Hukum Acara Pidana (KUHAP) adalah termasuk melakukan tembak mati di tempat pada orang yang di duga atau tersangka yang terkait dalam suatu tindak pidana termasuk kejahatan terorisme. Dasar hukum diskresi bagi petugas kepolisian negara Republik Indonesia (Polri) dalam melaksanakan tugasnya dapat dilihat pada Undang-undang Nomor 2 tahun 2002 tentang Kepolisian Negara Republik Indonesia Pasal 15 ayat (2) huruf k, Pasal 16 ayat (1) huruf 1, Pasal 18 ayat (1) Untuk kepentingan umum, pejabat Kepolisian Negara Republik Indonesia dalam melaksanakan tugas dan wewenangnya dapat bertindak menurut penilaiannya sendiri. Peraturan Kapolri Nomor 1 Tahun 2009 tentang penggunaan kekuatan dalam Tindakan Kepolisan ada beberapa prinsip dasar yang menjadi dasar pengunaan senjata api. Sesuai dengan Pasal 15 Peraturan Kepala Kepolisian Negara Republik Indonesia Nomor 1 Tahun 2009 Tentang Penggunaan Kekuatan Dalam Tindakan Kepolisian harus melakukan tindakan tembakan peringatan terlebih dahulu. Densus 88 sebagai pelaku operasi penumpasan terorisme harus memperhatikan asas praduga tak bersalah dengan cara menghindari tindakan yang sewenang-wenang dan berada di luar prosedur yang telah ditetapkan, baik dalam undang-undang maupun peraturan lainnya.

\section{DAFTAR PUSTAKA}

Indriyanto Seno Adji, Terorisme, "Perpu No.1 tahun 2002 dalam Perspektif Hukum Pidana" dalam Terorisme: Tragedi Umat Manusia, O.C. Kaligis \& Associates, Jakarta, 2001

M Fall, Penyaringan Perkara Pidana Oleh Polisi (Diskresi Kepolisian), Pradya Pramita, Jakarta, 1991

PAF Lamintang, Dasar-Dasar Hukum Pidana Indonesia, Penerbit Sinar Baru, Bandung, 1984 